\title{
BURIAL PRACTICES OF THE POPULATION FROM THE KONDA RIVER BASIN IN THE MESOLITHIC AND NEOLITHIC PERIODS
}

(C) 2020

\author{
Klementyeva Tatyana Yuryevna, researcher; specialist-archaeologist \\ Institute of History and Archaeology of Ural Branch of Russian Academy of Sciences \\ (Yekaterinburg, Russian Federation); Research and Analytical Center of Problems of Preservation \\ of Cultural and Natural Heritage "AV KOM - Nasledie» (Yekaterinburg, Russian Federation) \\ Pogodin Andrey Albertovich, deputy general director for research \\ Research and Analytical Center of Problems of Preservation of Cultural and Natural Heritage \\ «AV KOM - Nasledie» (Yekaterinburg, Russian Federation)
}

\begin{abstract}
The paper is dedicated to burial practices of the Stone Age population that inhabited the territory of the North-West Siberia. The source base is represented by 14 complexes. The burial grounds and solitary graves are located on high slopes in the terrace conifer forest areas along the tributaries of the Konda River. The Mesolithic burials date back to the period starting from the $9^{\text {th }}-8^{\text {th }}$ millennium $\mathrm{BC}$ through the end of the $7^{\text {th }}$ millennium BC, while the Neolithic can be traced starting from the $7^{\text {th }}-6^{\text {th }}$ millennium BC to the middle of the $4^{\text {th }}$ millennium BC. The taiga hunters traditionally buried their deceased relatives in the ground. The burials tend to be clustered into linear groupings within the cemetery area. Solitary graves are found on the territory of apparently abandoned settlements near the foundation pits of houses or inside them. Two forms of burial were practiced: inhumation and cremation followed by the burial of burnt remains. Generally, the dead were buried in the extended position, i.e., lying flat with arms and legs straight. The bodies were covered with red ocher, wrapped or swaddled, and put into graves. A special type of Mesolithic burials was «vertical» burials, i.e., the dead were placed into a vertical shaft like pits. The cremated remains were buried in ocher graves. The burned bones were placed in the center of each pit. Solitary burials prevailed. Less common were paired and multi-tire graves. Children were buried in the same way as adults, the age range of the dead varied from 5-7 to 60 years. The deceased were buried together with stone tools, jewelry, fragments of dishes, funeral and memorial food. The burial things were «prepared» following a special ritual - the blades of stone adzes were sharpened, the pottery was broken. There are signs of special respect to the skulls of the dead. The traditional burial practices of the taiga population from the Konda River Basin remained the same throughout the Stone Age.

Keywords: burial practices; Mesolithic; Neolithic; Western Siberia; Konda River Basin; burial grounds; burials in settlements; inhumation; cremation; vertical burials; ocher; swaddling; burial equipment; skull burial; ceramics; stone tools; bone pendants; resin beads; Shoushma type; radiocarbon dating.
\end{abstract}

\section{ПОЯСНЫЕ ПРЯЖКИ РАННЕСАРМАТСКОГО ВРЕМЕНИ ТУРГАЯ}

(C) 2020

Сеитов Абай Мейрамович, научный сотрудник отдела первобытной археологии; научный сотрудник лаборатории археологических исследований

Институт археологии им. А.Х. Маргулана (2. Алматы, Республика Казахстан); Костанайский государственный университет им. А. Байтурсынова (2. Костанай, Республика Казахстан)

Аннотация. Статья посвящена поясным пряжкам раннесарматского времени Тургая. Тургайский прогиб это обширная территория, расположенная в северо-западной части Казахстана. Тургайский прогиб на севере переходит в Западно-Сибирскую низменность, на юге - в Туранскую. На западе прогиб соприкасается с Зауральским плато, а на востоке - с Казахским мелкосопочником. В статье анализируются три пряжки, происходящие из погребения № 5А кургана 1 могильника Каратомар и кургана 1 курганной группы Кеныш 3, рассматривается культурно-хронологическая позиция поясных пряжек Тургая в контексте распространения подобных изделий поясной гарнитуры в степях Евразии. Также затронута проблема происхождения и хронологии этих предметов. Пряжки, подобные каратомарской, пока обнаружены только на территории от Средней Азии и Казахстана до Нижнего Поволжья. Пряжка из кургана Кеныш 3 находит аналогии от Волго-Донья до Северного Китая. Типы пряжек, подобные тургайским, бытовали во II-I вв. до н.э. Анализируемые пряжки следует рассматривать в контексте общей моды на ношение поясной гарнитуры из металла, кости и камня, связанной с военной активностью хуннов.

Ключевые слова: Степи Евразии; Северо-Западный Казахстан; Тургай; Тургайский прогиб; могильник Каратомар; курганная группа Кеныш 3; раннесарматское время; раннесарматская культура; сарматы; хунны; поясные пряжки; II-I вв. до н.э.; пантера; верблюд; гагат; глинистый сланец.

\section{Введение}

Тургайский прогиб расположен в северо-западной части Казахстана, на территории Костанайской обл. На севере Тургай соприкасается с Западно-Сибирской низменностью, на юге переходит в ТуранСамарский научный вестник. 2020. Т. 9, № 1 (30) скую низменность. На западе он ограничен Зауральским плато, а восточная часть является западной окраиной Казахского мелкосопочника [1, с. 18-25]. Эпоха ранних кочевников Тургая мало изучена, поэтому актуально исследование скифо-сарматских 
древностей. Данная статья посвящена трем поясным пряжкам раннесарматского времени из Тургая в контексте распространения аналогичных предметов поясной гарнитуры в степях Евразии. Затрагиваются вопросы их происхождения и хронологии (рис. 1).

\section{Общзая характеристика}

Пряжка из погребения № 5А кургана 1 могильника Каратомар (рис. 1: 2). Памятник расположен на территории района Беимбета Майлина (Костанайская обл.), на левом берегу тобольского рукава Каратомарского вдхр., у северо-восточной окраины пос. Халвай. В 2017 г. Тургайской археологической экспедицией начаты раскопки синташтинского кургана № 1 . В его насыпи на глубине 1 м были зафиксированы две впускные разновременные ямы, № 5 и № 5A, расположенные перпендикулярно друг другу. Яма № 5A прорезала восточную часть ямы № 5, относящуюся к савроматскому времени. Яма № 5А овальная, размерами 2,55 × 0,85 м, глубиной 0,4 м, ориентирована меридионально. Яма сильно нарушена грызунами. Часть костяка отсутствует. Судя по расположению костей ног, умерший находился в вытянутом положении головой на юг на деревянных носилках. Среди находок - железный меч без навершия и перекрестия, железные трехлопастные наконечники стрел с черешковым насадом, железное ложковидное изделие и бронзовая пряжка. Пряжка была обнаружена в восточной стенке ямы, на глубине 0,3 м, за носилками. Погребение относится к концу раннесарматской культуры II-I вв. до н.э. [2, с. 316-327].

Пряжка бронзовая ажурная рамчатая, литая, прямоугольной формы с закругленными углами. Размеры: $9,6 \times 4,9 \times 0,8 \mathrm{~cm}$. Одна треть изделия обломана. С лицевой стороны, слева по углам рамки, имеются два отверстия для крепления к ремню. С той же стороны на узкой стороне рамки находится цельнолитой крюкзастежка. Внутри рамки заключен рельефный рисунок, сюжетом которого является сцена нападения кошачьего хищника (пантеры) на верблюда. Тело пантеры изогнуто, задняя часть и спина показаны в профиль, а передняя, включая шею, голову и лапы - анфас, сверху. Пантера, привстав на задние лапы, навалилась на жертву сверху, пастью вцепилась в основание ее шеи, левой лапой ухватилась за передний горб, а правой - за шею. Задние лапы хищника согнуты в коленях и опираются на нижнюю часть рамки, а длинный изогнутый хвост приподнят и соприкасается с верхней частью рамки. На боку, в виде коротких, слегка изогнутых углублений, изображены ребра. Шерсть на шее пантеры показана косыми вертикальными линиями. Глаза в виде небольших впадин. От фигуры верблюда сохранилась только его передняя часть с горбом и фрагмент задней ноги. Верблюд упал на передние ноги, поджал их, вытянул шею и приподнял голову. Его морда примыкает к задней левой ноге пантеры (возможно, он кусает ее). Шёрстный подвес на шее изображён тонкими косыми линиями, а на верхней части ноги шерсть показана вертикальной «елочкой». Голова верблюда выполнена схематично, заметна горбоносая морда, разрез пасти, овальное ухо с ложбинкой. На голове «шапка» густой шерсти, подчеркнутая горизонтальными линиями. На задней части головы в виде вертикальной, сломанной под тупым углом рельефной полоски, изображен ре- мень упряжки с поводом, основная часть которого тянется вдоль шеи в сторону горба.

Пряжки из погребения кургана 1 курганной групnы Кеныш 3 (рис. 1: 3-4). Памятник расположен в 7 км к Ю3 от г. Лисаковска (Костанайская обл.). Исследован Тургайской археологической экспедицией в 1995 г. под руководством В.Н. Логвина. Состоит из двух разновременных курганов - эпохи раннего железа и средневековья [3, с. 376-381]. Курган № 1, диаметром 25 м, высотой 1,25 м, окружен кольцевым рвом. В центре подкурганной площадки обнаружена подпрямоугольная яма, ориентированная по линии СЗ-ЮВ. В северо-западном секторе ямы, на глубине 1,9 м от древней поверхности, обнаружено парное захоронение. Умершие, условно обозначенные как «южный» и «северный», находятся вытянуто на спине, головами на юг с небольшим отклонением к западу. Под костяками прослеживается органический тлен. Среди находок - железные трехлопастные наконечники стрел с черешковым насадом, подпрямоугольные пластины, меч и кинжал с прямым перекрестием, серповидным и рожковидным навершиями, фрагменты деревянной посуды с бронзовой проволокой, бронзовые втульчатые трехлопастные и трехгранные наконечники стрел и костяные пряжки, находившиеся в районе пояса, на тазобедренных костях «северного» костяка. Погребение относится к концу раннесарматской культуры. Наиболее вероятной датой следует считать II в. до н.э.

Костяные пряжки (2 экз.) располагались сверху, поперек тазобедренных костей. Они подпрямоугольной формы, пластинчатые, выпукло-вогнутые в сечении (по мнению Л.Л. Гайдученко, изготовлены из рога оленя). Пряжка с правой стороны тазобедренной кости, размерами 10,8 × 4,3 ×0,4 см (рис. 1: 3). На одном конце изделия просверлены два округлых отверстия. По-видимому, их было три (одно было расположено в обломанном уголке), они располагались по контуру воображаемого треугольника. На другом конце, по середине, выполнено два разных отверстия. Одно, округлое, по центру закраины изделия, другое - вытянутое овальное $(2,17 \times 0,63 \mathrm{~cm})$, расположено поперек пряжки и предназначено для пропускания конца ремня. Пряжка с левой стороны тазобедренной кости размерами 10,9 × 4 ×0,3 см (рис. 1: 4). На одном конце изделия расположены три округлых отверстия, аналогичные первому экземпляру. На другом конце, по середине, изначально тоже было отверстие, которое не сохранилось. По-видимому, пряжки пришивались к поясу, в котором проделывалось овальное отверстие для пропускания конца ремня.

\section{обсуждение}

Бронзовая пряжка из Каратомар сопоставима с экземплярами раннесарматского времени. Они делятся на два варианта: с сюжетом лежащего верблюда и нападения пантеры на верблюда. Первый вариант пряжек пока известен в основном только в Волго-Донье, изредка отмечен в Средней Азии и Южном Зауралье. Они датируются II-I вв. до н.э. [4, с. 386388 , fig. 35 ; 5 , рис. $1: 1-3$, рис. 2: 1-5]. Пряжек второго варианта известно всего с десяток (рис. 2). В стилистическом отношении они близки, изображения на них выполнены схематично [6, с. 94, рис. 55: 1-6]. В Средней Азии такие пряжки происходят из Лявандакского и Шахривайронского могильников [7, 
c. 35-36, с. 179-186] (рис. 2: 9-10). Такие же образцы встречаются и в нашей стране. Одна в Центральном Казахстане в кургане 1 могильника Карамурун II [8, c. 364,402 , рис. 64]. Три другие из Западного Казахстана, это пряжки из захоронения Тастагым [9, c. 186-194, рис. 2], могильника Талдысай I (к. 5) [10, рис. 2: 4] и могильника Жусандыой [11, с. 774] (рис. 2: 2-5). Схожий образец найден в кургане у дер. Ванюши (Челябинская обл.) [12, рис. 12: 49] (рис. 2: 11). Подобные находки встречаются и в Нижнем Поволжье. К их числу относится экземпляр из могильника Писаревка II (п. 2, к. 6) [13, с. 252, рис. 2: 11], могильника Петрунино II (п. 14, к. 1) [14, c. 152, рис. 4: 14] и могильника Кривая Лука VII (п. 28, к. 9) [15, рис. 6А: 9] (рис. 2: 6-8).

Наибольшее сходство каратомарская пряжка имеет с изделиями из Жусандыой и Писаревки. Почти совпадает ширина (жусандыойская $-4,8 \times 10,8 \mathrm{~cm}$, писаревская $-4,8 \times 11,3$ см), изображение горбоносой морды верблюда, «шапки» шерсти, упряжки и других деталей. На писаревской пряжке более детализированы части животных.

Как известно, в результате многократных копирований поясных пряжек и блях, их последующая копия отличалась от предыдущего оригинала уменьшенными размерами и более смазанными деталями [16, с. 19]. Пряжки с сюжетом нападения пантеры на верблюда (кроме писаревской, жусандыойской и каратомарской), меньше по размеру, схематичнее и менее детализованные. Отсутствие изображения упряжи, повода, «шапки» шерсти и других деталей, возможно, свидетельствует об их относительно позднем изготовлении или неумелой копией. Создается впечатление, что эти три экземпляра были более близки к прототипу. Возможно, что писаревская пряжка являлась исходной моделью для каратомарской и жусандыойской.

Хронология пряжек этого типа II-I вв. до н.э. в основном не вызывает сомнений в научном мире [6, c. 94; 5, c. 73]. Это подтверждает и датировка погребения с пряжкой из Писаревки II, откуда происходит лучковая фибула с подвязным приемником II-I вв. до н.э. [13, с. 255-256]. Такие пряжки обнаружены на территории от Средней Азии и Казахстана до Нижнего Поволжья и не имеют аналогий в других частях Евразии [4, p. 385]. М.А. Дэвлет и А.С. Скрипкин предполагают их восточное происхождение, мода на которые сформировалась у хунну, а затем распространилась у других племен $[16$, с. $18-19 ; 15$, с. 25]. Е.Ф. Королькова высказала мысль о казахстанскоюжноуральском или сибирском происхождении такого типа ременной гарнитуры [6, с. 93]. Схожую мысль высказывал О.В. Обельченко, отнесший их к скифо-сарматскому искусству Южного Приуралья и Центрального Казахстана [7, с. 185-186]. А.К. Акишев включил тастагымскую пряжку в круг савроматских памятников Южного Приуралья [9, с. 193]. В.П. Глебов рассматривает такие пряжки как самостоятельный «сарматский» или «сарматско-среднеазиатский» тип в рамках общей моды на ношение зооморфных поясных блях в конце раннесарматского времени, поддерживая идею А.С. Скрипкина о локальных центрах производства таких изделий на До- ну, в Поволжье и Средней Азии, ориентированных на восточные образцы $[5$, с. $75 ; 15$, с. 25$]$.

На определенную связь рассматриваемых пряжек со звериным стилем савроматского времени может указывать не только сюжет, поза животных, трактовка шерсти на ногах и шее, но и другие детали, которые присутствуют на экземплярах из Писаревки, Каратомар и Жусандыой. Это воспроизведение горбоносой морды и «шапки» шерсти на голове верблюда. На карамурунской пряжке у верблюда заметен хохолок, на что обращал внимание А.К. Акишев [9, c. 190]. Перечисленные элементы в образе верблюда характерны для звериного стиля сако-савроматского времени [6, с. 89-90]. По-видимому, это свидетельствует о преемственности художественной традиции ранних кочевников восточно-евразийских степей.

Пряжки из Кеныша 3 сопоставимы с рядом экземпляров, отмеченных в Евразии (рис. 3). Ближайшие аналогии костяным прямоугольным пластинчатым пряжкам происходят из кургана Жалтырь в Северном Казахстане (II-I вв. до н.э.) [17, с. 72 , табл. 39: 10] и могильника Талдысай 1 (п. 2, к. 5) в Западном Казахстане, относящегося ко II в. до н.э. [10, с. 104, рис. 2: 3] (рис. 3: 3-4). Аналогичные по форме экземпляры отмечены в памятниках Средней Азии последней трети II в. до н.э. - I в. н.э. (рис. 3: 57). Так, пластинчатые пряжки из кости найдены в Куюмазарском могильнике [18, табл. 42: 54], из гагата (гешира) в кургане 2 Кызылтепинского могильника [7, с. 40-44; 4, fig. 10: 2-3]. В Волго-Донье подобные изделия из гагата найдены в погр. 4 кург. 27 у ст. Жутово (II-І вв. до н.э.) [15, рис. 6А: 1-2] (рис. 3: 8-9). Костяная пряжка аналогичной формы происходит из Заволжья в погребении у с. Альт-Веймар [19, c. 47-48, рис. 25: 7] (рис. 3: 10). Подобные костяные пряжки известны и в Западной Сибири (рис. 3: 1112). Это экземпляр из погр. 21 мог. Фирсово-XI в Приобье. В целом этот могильник датируется в пределах І в. до н.э. - I в. н.э., хотя некоторые погребения могли появиться и в более раннее время [20, c. 225 , pис. 2: 5]. Другая пряжка найдена в жилище 1 поселения Каргат 4 (V-III вв. до н.э.) в Барабинской лесостепи [21, с. 81, 90, рис. 66: 12]. Несколько аналогичных изделий найдено и в Южной Сибири (рис. 3: 13-14). Так, один экземпляр из гагата обнаружен в хуннском могильнике Ала-Тей 1 (II-I вв. до н.э.) в Туве [22, рис. 4:2], другой из могильника Калы на Среднем Енисее [15, рис. 6Б: 2].

Больше всего подобных пряжек происходит из хуннских памятников Забайкалья II-I вв. до н.э. (рис. 3: 15-24). На Иволгинском городище и могильнике обнаружено несколько пластинчатых экземпляров из глинистого сланца, кости и рога $[23$, табл. 37 : 2, табл. 53: 7, табл. 96: 16, табл. 148: 7 , табл. 182: 7, 10; 24, табл. 40: 3]. В могильнике Дырестуй такие пряжки, изготовленные из глинистого сланца, найдены в погребениях № 52, 114, 123. Благодаря обнаружению китайских монет «у-шу» в разных участках могильника, данный памятник датируется от конца II в. до н.э. - до I в. н.э. [25, табл. 36: 1-2, табл. 98: 2, табл. 113: 8]. Аналогичный экземпляр из гагата отмечен при исследовании могильника Даодуньцзы в Северном Китае [15, рис. 6Б: 1] (рис. 3: 25). 

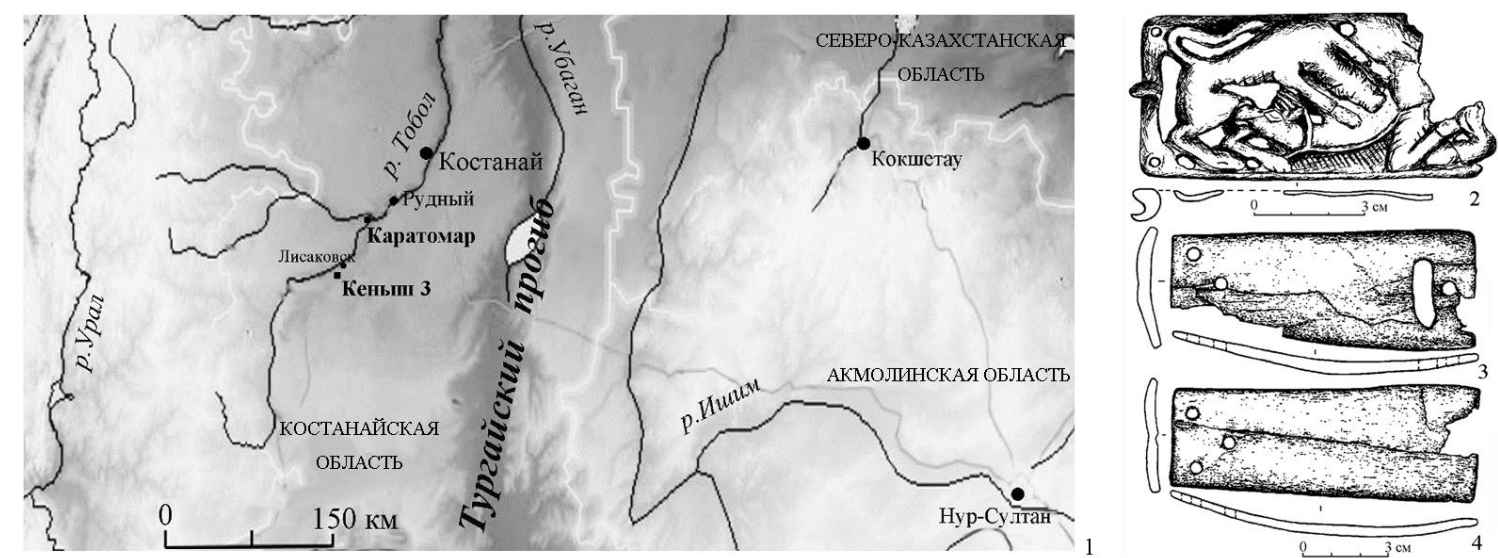

Рисунок 1 - Пряжки раннесарматского времени Тургая:

1 - локализация могильника Каратомар и курганной группы Кеныш 3; 2- бронзовая пряжка из погребения № 5А мог. Каратомар; 3, 4- костяные пряжки из кургана 1 курганной группы Кеныш 3

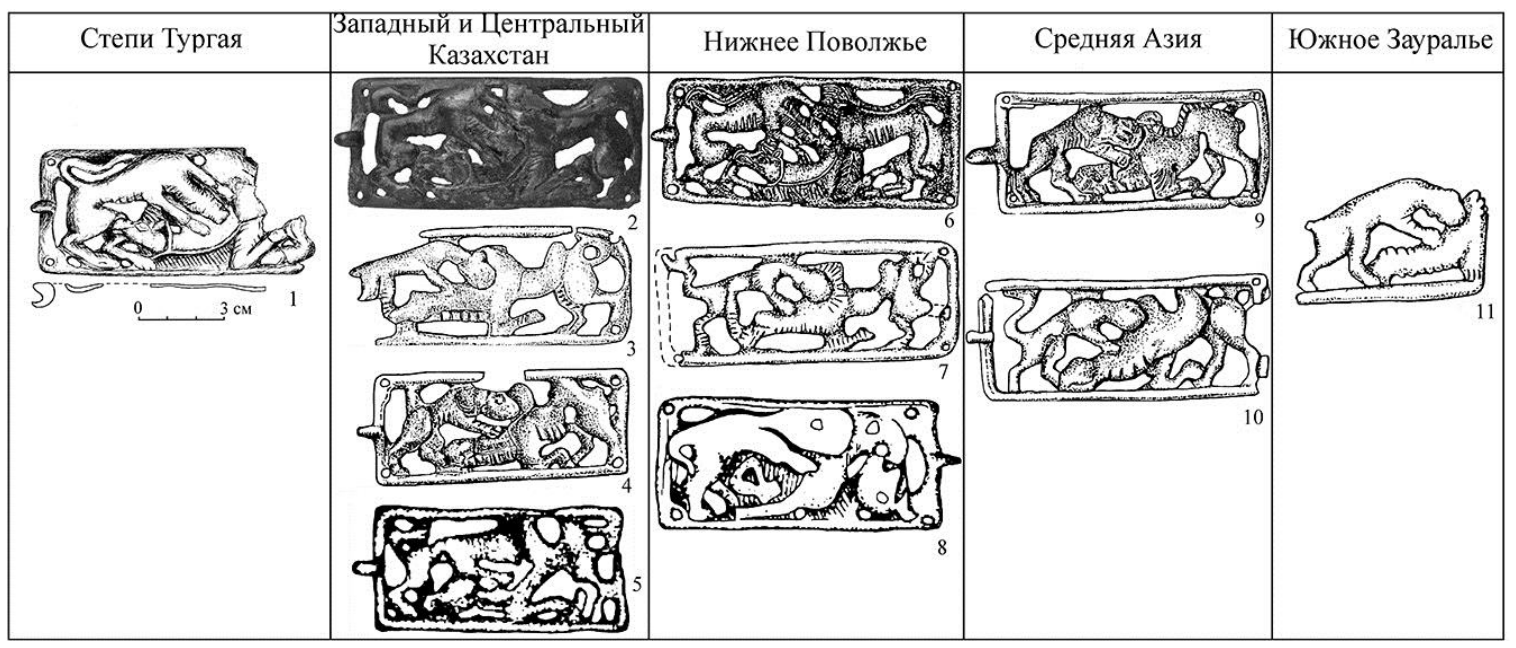

Рисунок 2 - Каратомарская пряжка и ее аналогии:

1 - яма № 5А к. 1 мог. Каратомар (по: [2]); 2- мог. Жусандыой (по: [11]); 3- к. 1 мог. Карамурун II (по: [6]); 4- погр. Тастагым (по: [6]); 5- к. 5 мог. Талдысай I (по: [10]); 6- п. 2 к. 6 мог. Писаревка II (по: [13]); 7- п. 14 к. 1 мог. Петрунино II (по: 14]); 8- п. 28 к. 9 мог. Кривая Лука VII (по: [15]);

9- к. 16 мог. Лявандак; 10- к. 2 мог. Шахривайрон (по: [6]); 11 - курган у дер. Ванюши (по: [12])

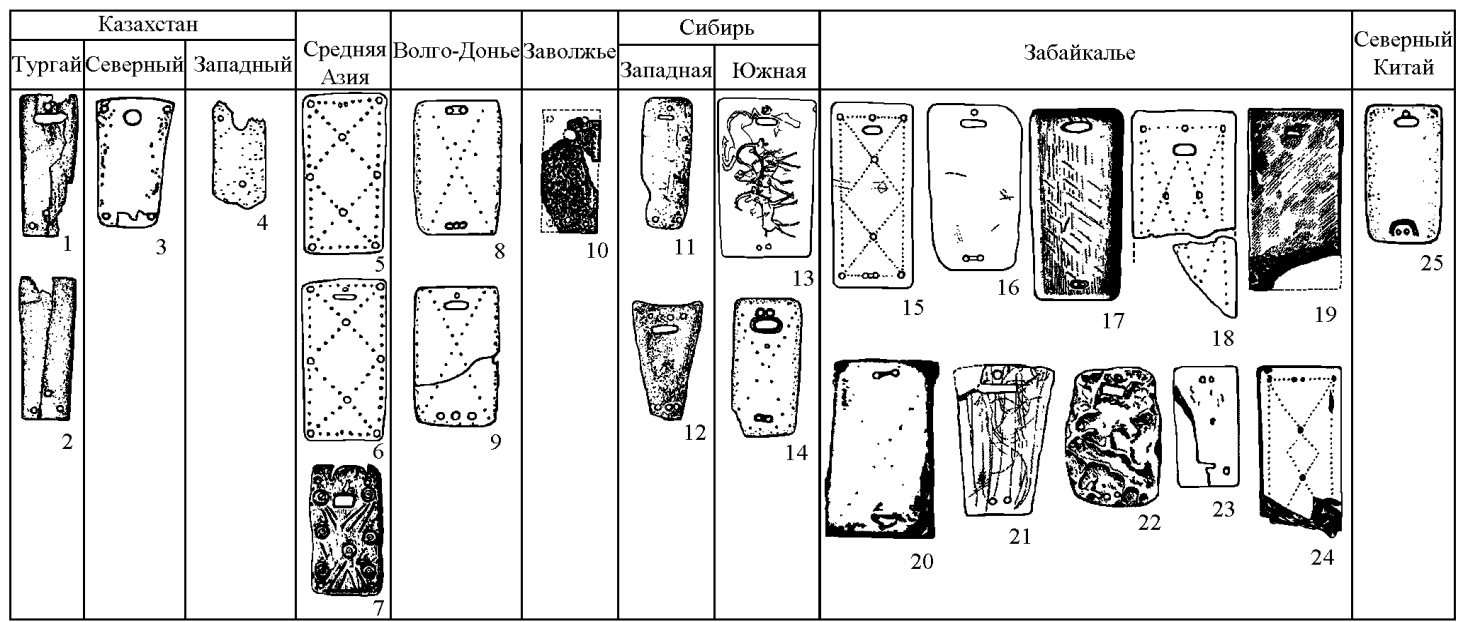

Рисунок 3 - Пряжки из Кеныша 3 и их аналогии:

1-2 - к. 1 Кеныш 3; 3- курган Жалтырь (по: [17]); 4- п. 2 к. 5 мог. Талдысай 1 (по: [10]);

5-6- к. 2 мог. Кызылтепе (по: [4]); 7- мог. Куюмазар (по: [18]); 8-9- п. 4 к. 27 у ст. Жутово (по: [15]); 10- погр. у с. Альт-Веймар (по: [19]); 11 - п. 21 мог. Фирсово-ХІ (по: [20]);

12 - жилище 1 поселения Каргат 4 (по: [21]); 13-мог. Ала-Тей 1 (по: [22]); 14- мог. Калы (по: [15]); 15-16 (п. 52), 17 (п. 114), 18 (п. 123) - мог. Дырестуй (по: [25]); 19-23-Иволгинское городище (по: [23]); 24- Иволгинский могильник (по: [24]); 25- мог. Даодуньцзы (по: [15]).

$1-4,7,10-12,21-23$ - кость и рог; $5,6,8,9,13,14,25$ - гагат; 15-20, 24- глинистый сланец 


\section{Заключение}

Таким образом, пряжки из Каратомар и Кеныша 3 имеют довольно много аналогий в степях Евразии во II-I вв. до н.э. Их следует рассматривать в контексте общей моды на ношение поясной гарнитуры из металла, кости и камня, связанной с военной активностью хуннов. Пряжки, аналогичные кенышевской, бытовали в обширной зоне от Северного Китая до Волго-Донья, хотя к настоящему времени наибольшая их концентрация отмечена в хуннских памятниках Забайкалья. По-видимому, непосредственное развитие таких экземпляров связано с племенами, входящими в хуннский союз. Пряжки с изображением нападения пантеры на верблюда пока известны только в погребениях раннесарматского круга от Средней Азии и Казахстана до Нижнего Поволжья. Поэтому маловероятно связывать их непосредственно с хуннами. По-видимому, в рамках моды на ажурные пряжки, в среде сарматов или родственных им племен был выработан данный изобразительный сюжет. Поэтому такие экземпляры бытовали только на обозначенной территории.

Последние века до нашей эры, отмечены новым импульсом воздействия центральноазиатского происхождения. На сарматских материалах этого периода наблюдается яркий пласт восточных инноваций в вооружении, поясной гарнитуре, предметах быта, украшениях и т.д. Главным образом, эти изменения связаны с военной активностью хунну, приведшей к передвижениям многих племен, падению Греко-Бактрийского царства и другим событиям. Все это способствовало не только усилению различных контактов между племенами и народами, но и миграции кочевников с востока на запад, что подтверждается в письменных источниках, на археологическом и антропологическом материалах [26, с. 219-221; 15, с. 25-29].

\section{Список литературы:}

1. Бобоедова А.А. Рельеф // Геология СССР. T. XXXIV. Кн. 1. М.: Недра, 1971. С. 18-25.

2. Логвин А.В., Шевнина И.В., Сеитов А.М. Раннесарматское погребение кургана 1 могильника Каратомар // Маргулановские чтения - 2019: мат-лы междунар. археол. науч.-практ. конф., посвящ. 95летию со дня рожд. выдающегося казахстанского археолога К.А. Акишева. Нур-Султан: Евраз. Нац. ун-т, 2019. С. 316-327.

3. Базарбаева Г.А., Подзюбан Е.В. Курганная группа Кеныш-3 // Топорковские чтения. Рудный: Рудненский индустриальный институт, 1997. Вып. 3. C. $376-381$.

4. Brosseder U. Belt Plaques as an Indicator of EastWest Relations in the Eurasian Steppe at the Turn of the Millennia // Xiongnu archaeology. Multidisciplinary Perspectives of the First Steppe Empire in the Inner Asia. Bonn: Rheinische Friedrich-Wilhelms-Universität, 2011. P. 349-424.

5. Глебов В.П. Пряжки с зооморфными изображениями в раннесарматской культуре Нижнего Подонья // Константин Федорович Смирнов и современные проблемы сарматской археологии: мат-лы IX междунар. науч. конф. «Проблемы сарматской археологии и истории», посв. 100-летию со дня рожд. К.Ф. Смирнова. Оренбург: Оренб. гос. пед. ун-т, 2016. С. 69-79.

6. Королькова Е.Ф. Звериный стиль Евразии. Искусство племен Нижнего Поволжья и Южного При- уралья в скифскую эпоху (VII-IV вв. до н.э.). Проблемы стиля и этнокультурной принадлежности. СПб.: Петербургское Востоковедение, 2006. 272 с.

7. Обельченко О.В. Культура античного Согда. По археологическим данным VII в. до н.э. - VII в. н.э. М.: Наука, 1992. 256 с.

8. Кадырбаев М.К. Памятники тасмолинской культуры // Маргулан А.Х., Акишев К.А., Кадырбаев М.К., Оразбаев А.М. Древняя культура Центрального Казахстана. Алма-Ата: Наука, 1966. С. 303-433.

9. Акишев А.К. Новые художественные бронзовые изделия сакского времени // Прошлое Казахстана по археологическим источникам. Алма-Ата: Наука, 1976. С. 183-195.

10. Мамедов А.М., Виноградов С.М. Катакомбные погребения раннего железного века могильника Талдысай I (Актюбинская область) // Этнические взаимодействия на Южном Урале. Челябинск: ЮУрГУ, 2009. C. 102-106.

11. Katalog: Objekte 490-530 // Unbekanntes Kasachstan Archologie im Herzen Asiens. Bochum: Dt. Bergbau-Museum, 2013. Р. 757-777.

12. Таиров А.Д. Периодизация памятников ранних кочевников Южного Зауралья 7-2 вв. до н.э. // Сарматские культуры Евразии: проблемы региональной хронологии: докл. к 5 междунар. конф. «Проблемы сарматской археологии и истории». Краснодар: OОО «Фирма НСС», 2004. С. 3-21.

13. Мамонтов В.И. Сарматские погребения из курганного могильника Писаревка II // Нижневолжский археологический вестник. 2002. Вып. 5. С. 251-259.

14. Сергацков И.В. Новые данные к хронологии раннесарматской культуры // Российская археология. 1995. № 1. С. 148-158.

15. Скрипкин А.С. Новые аспекты в изучении истории материальной культуры сарматов // Нижневолжский археологический вестник. 2000. Вып. 3. С. $17-40$.

16. Дэвлет М.А. Сибирские поясные ажурные пластины II в. до н.э. - І в. н.э. // Свод археологических источников. М.: Наука, 1980. Вып. Д4-7. 66 с.

17. Хабдулина М.К. Степное Приишимье в эпоху раннего железа. Алматы: Гылым, 1994. 170 с.

18. Мандельштам А.М. Кочевое население Среднеазиатского междуречья в последние века до нашей эры и первые века нашей эры // Степная полоса Азиатской части СССР в скифо-сарматское время. М.: Наука, 1992. С. 107-116.

19. Симоненко А.В., Лобай Б.И. Сарматы северозападного Причерноморья в І в. н.э. Киев: Наукова думка, 1991. $112 \mathrm{c.}$

20. Фролов Я.В., Шамшин А.Б. Могильник раннего железного века фирсовского археологического микрорайона (Фирсово-III, XI, XIV) // Итоги изучения скифской эпохи Алтая и сопредельных территорий: сб. науч. ст. Барнаул: Алтайский гос. ун-т, 1999. C. 219-226.

21. Полосьмак Н.В. Бараба в эпоху раннего железа. Новосибирск: Наука, 1987. 144 с.

22. Килуновская М.Е., Леус П.М. Новые данные по социальной структуре населения Тувы в конце I тыс. до н.э. // Мужской и женский мир в отражении археологии: мат-лы всерос. с междунар. уч. науч. конф. Уфа: Институт истории, языка и литературы Уфимского федер. исслед. центра РАН, 2018. С. 124-134. 
23. Давыдова А.В. Иволгинский археологический комплекс. Т. 1: Иволгинское городище // Археологические памятники сюнну. СПб.: Фонд «АзиатИКА», 1995. Вып. 1.97 с.

24. Давыдова А.В. Иволгинский археологический комплекс. Т. 2: Иволгинский могильник // Археологические памятники сюнну. СПб.: Петербургское Востоковедение, 1996. Вып. 2. 176 с.

25. Миняев С.С. Дырестуйский могильник // Археологические памятники сюнну. СПб.: Филфак СПбГУ, 2007. Вып. 3. 233 с.
26. Скрипкин А.С. О восточных связях сарматов во II-I вв. до н.э. // Сарматы и внешний мир: мат-лы VIII всерос. (с междунар. участием) науч. конф. «Проблемы сарматской археологии и истории». Уфа: Институт истории, языка и литературы; Уфимский науч. центр РАН; центр «Наследие», 2014. С. 216-222.

Статья подготовлена в рамках грантового финансирования Комитета науки Министерства образования и науки Республики Казахстан, ИРН проекта АР05131573.

\title{
THE BELT BUCKLES OF THE EARLY SARMATIAN PERIOD OF TURGAY
}

(C) 2020

Seitov Abay Meiramovich, researcher of Prehistoric Department; researcher of Archaeological Laboratory

A.Kh. Margulan Institute of Archaeology (Almaty, Republic of Kazakhstan);

Kostanay State University A. Baitursynov (Kostanay, Republic of Kazakhstan)

Abstract. The paper is devoted to belt buckles of the early Sarmatian period of the Turgay steppes. Turgay deflection is a vast territory located in the north-western part of Kazakhstan. In the north, Turgay deflection turns into the west Siberian lowland, and in the south it turns into the Turan lowland. In the west, the bend touches the Trans-Ural plateau, while in the east - the Kazakh hills. Three buckles originating from burial № 5A of mound 1 of the Karatomar burial ground and mound 1 of the Kenysh 3 mound group are analyzed. The paper deals with the cultural and chronological position of Turgay belt buckles in the context of the distribution of such products of the belt headset on the territory of Eurasia. The problem of the origin and chronology of these items is also touched upon. Buckles similar to the Karatomar one have so far been found only on the territory from Central Asia and Kazakhstan to the Lower Volga region. Kenysh buckle finds an analogy from the Volga-Don interfluves to the north of China. In General, types of buckles, similar to Turgay, existed in the II-I centuries BC. The studied buckles should be considered in the context of the general fashion for wearing a belt headset made of metal, bone and stone, associated with the military activity of the Huns.

Keywords: Steppes of Eurasia; North-Western Kazakhstan; Turgay; Turgay deflection; Karatomar burial ground; Kenysh 3 barrow group; early Sarmatian time; early Sarmatian culture; Sarmatians; Huns; belt buckles; II-I centuries $\mathrm{BC}$; panther; camel; jet; clay shale.

$* * *$

УДК 902.26

DOI 10.24411/2309-4370-2020-11204

Статья поступила в редакцию 28.01.2020

\section{КУРГАНЫ САМАРСКОЙ ОБЛАСТИ В ФОКУСЕ СПУТНИКОВЫХ СНИМКОВ}

(C) 2020

\author{
Вальков Денис Владимирович, начальник отдела археологических исследований \\ Научно-производственный цеентр «Универсальные технологии и разработки» \\ (2. Самара, Российская Федерация)
}

Аннотация. Статья сфокусирована на двух археологических проблемах: корректность системы учета па-
мятников археологии и эффективность их обнаружения, особенно в зонах предстоящих строительных работ.
Актуальность проблем раскрыта автором на примере истории исследования курганного могильника «Самар-
ский (Просвет) І» и на примере обследования его территории методом анализа разнородных данных дистан-
ционного зондирования Земли (ДЗ3). Установлено, что за период 1973-2016 гг. памятник обследовали не
менее 8 экспедиций. За это же время накопившиеся ошибки в описании привели к тому, что в системе учета
объектов археологического наследия Самарской области этот памятник под одним названием зафиксирован
под двумя номерами и в двух административных районах. На территории памятника автор сформировал
набор данных ДзЗ, включающий архивные и современные космические снимки. Затем все эти данные и ме-
стоположения курганов, выявленных предшествующими исследователями, в специализированном про-
граммном продукте приведены к единой проекции. По разным данным д33, выделяется от 31 до 180 зон ха-
рактерной контрастной пикселизации. Местоположения всех курганов, ранее выявленных в поле, совпадают
с ними. Следовательно, многие из этих зон также могут быть полностью распаханными курганами, сохран-
ности которых угрожает строительство нефтепроводов по соседству. По этой методике произведена провер-
ка территории еще четырех курганных могильников, обследованных в 2015-2017 гг. и расположенных в зо-
нах строительства. На них обнаружены курганы, не выявленные исследователями ранее и, соответственно, по-
врежденные в ходе строительных работ. Выводы: полевому археологическому обследованию должен предше-
ствовать анализ разнородных данных ДЗ3; наиболее надежным методом является исследование курганных мо-
гильников раскопом сплошной площадью, накрывающим и межкурганное пространство. Однако этот же ме-
тод, как наиболее затратный, требует корректировки по данным ДзЗ и иными, не инвазивными методами. 